\section{Kristinn R. Pórisson}

Höfundur er prófessor í tölvunarfræði við Háskólann í Reykjavík, og stjórnandi Vitvélastofnunar Íslands

thorisson@gmail.com

\title{
Ný tækni - nýir tímar
}

Greind er merkilegt fyrirbæri. Pessi lífeðlislegu upplýsingaferli sem við köllum í daglegu tali „hugsun“ gera pér, lesandi góður, kleift að lesa pessar línur - og mér að skrifa pær.

En hvað er hugsun? Hugsun er framleidd í heilanum, og til að veran geti talist vitiborin parf hún að geta framleitt fjölda vel valdra hugsana í réttri röð - hugsanakeðjur sem geta ekki aðeins náð settum markmiðum heldur líka sett sér sín eigin markmið og undirmarkmið í ljósi aðstæðna og parfa hverju sinni. Og til að læra purfa pessi hugsanaferli að batna með reynslunni. Hugsun er ein af fjölmörgum afleiðingum lagskiptra ferla, par sem ferli í hverju lagi nýta og bæta virkni ofan á pau sem fyrir eru. Talið er nokkuð víst að efsta lagið - pað er pað sem við í daglegu tali köllum "greind“, beinist að meðferð upplýsinga sem við ýmist höfum beinan aðgang að pegar við hugsum, til dæmis um hvar við settum húslyklana, og upplýsinga sem við höfum nánast engan aðgang að, eins og til dæmis hvernig vöðvunum er stjórnað pegar við grípum bolta.

Til að öðlast góðan vísindalegan skilning á greind parf að gera grein fyrir pví sem gerist í hverju pessara laga. Раð hefur reynst erfitt, hvort sem er ofan frá og niður eða að neðan og upp. Hugsanafær heili homo sapiens er samsettur úr margra ára pjálfun $10 \mathrm{E}^{11}$ taugafrumna, sem hver byggir á efnafræðilegum, lífeðlislegum og rafeðlislegum ferlum, og eru tengdar saman í flókið net taugafrumnaklasa. Saman myndar petta heildstætt kerfi sem að langstærstum hluta er, frá vísindalegu sjónarmiði, ennpá eitt stórt spurningarmerki.

Gervigreind er sprottin af pessum meiði: Um aldamótin 1900 var „,computer“ ekki nafn á tæki heldur starfsheiti peirra sem sátu og reiknuðu allan daginn í huganum. Hugmyndin er í grunninn einföld: Ef hugsun er upplýsingafyrirbæri er ekkert sem mælir gegn pví að búa til vél sem hugsar.

Síðan eru liðin mörg ár. Framfarir á pessu sviði síðasta áratug, sérstaklega hvað varðar flokkunarkerfi (classifiers), nánar tiltekið djúptauganet (tegund gervitauganeta), hafa lækkað kostnað við að pjálfa vélar í greiningu flókinna mynstra. Og par sem gagnamagn heims vex veldislega getur slík sjálfvirkni í vöru og pjónustu af öllum tegundum og gerðum ekki bara sparað, heldur líka búið til glæný tækifæri. Heilbrigðisgeirinn er parna engin undantekning. Раð er mikilvægt - í raun pjóðprifamál - að koma gervigreindartækni sem fyrst inn í atvinnugeirann á Íslandi, pví ef greind liggur að baki öllu sem mannskepnan hefur áorkað í vísindum og tækni síðustu 2000 árin, er sjálfgefið að efling hennar verði allveruleg pegar hugsandi vélar fara að hjálpa til. pað er hins vegar ekki á allra færi að ráða til sín gervigreindarsérfræðinga „bara til að prófa", og par koma stofnanir eins og Vitvélastofnun Íslands inn í myndina en hún aðstoðar fyrirtæki við að próa frumgerðir og koma sér upp pekkingu á pessu sviði.

Á Íslandi höfum við náð aðeins lengra en hin Norðurlöndin hvað varðar gervigreind: Töluverð reynsla er komin á samstarf Vitvélastofnunar við atvinnuveginn og verulega aukinn áhugi síðasta árið og Gervigreindarsetur HR sem stofnað var fyrir rúmum 10 árum pjálfar fjölda nemenda í gervigreind og skyldum fögum á ári hverju. Hin Norðurlöndin hafa verulega reynslu af stofnunum sem vinna að hagnýtum rannsóknum í samstarfi við atvinnuveginn, og háskólarannsóknarsetrum af öllum tegundum og gerðum, pó ekki með megináherslu á sjálfvirkni og gervigreind.

Til að halda forskotinu og flýta rannsóknum á sviðinu vil ég benda vísindasamfélaginu á að auka áherslu á rannsóknir á lagskiptum kerfum; framfarir á pví sviði myndu hafa veruleg jákvæð áhrif á ekki bara gervigreind heldur líka tölvunarfræði, stærðfræði, líffræði og verkfræði. Ekkert vit er að rannsaka hagkerfi, vistkerfi og greind einungis með verkfærum 18. aldar - bókum, blöðum, pennum og tölfræði: Eins og stjarneðlisfræðingar og veðurfræðingar vita mætavel eru tölvulíkön haldbærasti kosturinn til að prufukeyra kenningar um flókin kerfi og finna götin í pekkingunni. Pess vegna er líka nauðsynlegt að kenna smíði - tölvulíkanasmíði. Petta vissu upphafsmenn cybernetics líka - til dæmis Ross Ashby, Norbert Wiener, og Heins von Foerster - jafnvel fyrir tíma tölvunnar.

En eru vélar nútímans virkilega "greindar" á sama hátt og pú og ég? Svarið er stutt: Nei. Pað er margt sem skilur á milli. Pegar pú, lesandi góður, hugsar um hugsun pá ertu að gera eina af afleiðingum gríðarlegs magns flókinna lagskiptra ferla að viðfangsefni peirra sjálfra - með „sjálfsskoðun“. Petta er kannski ekki eins flókið og pað hljómar - pegar við skiljum umheiminn býr hugurinn til líkön af pví sem berst inn fyrir skilningarvitin; sjálfsskoðun er hið sama nema hvað líkönin fjalla pá um líkönin sjálf. Í Gervigreindarsetri HR teljum við sjálfsskoðun gegna lykilhlutverki í skilningi. Við höfum á peim forsendum smíðað vélar sem skilja með pá yfirtilgátu að leiðarljósi að raunveruleg (gervi-) greind krefjist raunverulegs skilnings. ${ }^{1}$

Notkun gervigreindar í meðferð gríðargagna fyrirtækja á hug allra um pessar mundir, og pað er skiljanlegt. Margir tala par um byltingu og pað má vel vera. En byltingin er bara rétt að byrja.

1. Thórisson KR, Kremelberg D, Steunebrink BR, Nivel E. About Understanding. In B. Steunebrink et al. (eds.), Proc. 9th Intl. Conf. on Artificial General Intelligence (AGI-16). New York City 2016: 106-11. 